\title{
Red clover - a legume showing tolerance to clover root weevil
}

\author{
B.M. COOPER ${ }^{1}$, J.R. CRUSH ${ }^{2}$, D.R.WOODFIELD ${ }^{3}$, B.E. WILLOUGHBY ${ }^{2}$ and K.A. PANCKHURST ${ }^{1}$ \\ ${ }^{1}$ AgResearch Kerikeri, P.O. Box 23, Kerikeri \\ ${ }^{2}$ AgResearch, Ruakura Research Centre, PB 3123 Hamilton \\ ${ }^{3}$ AgResearch, Grasslands Research Centre, PB 11008, Palmerston North \\ bruce.cooper@agresearch.co.nz
}

\begin{abstract}
Clover root weevil (CRW) has now spread through the northern North Island, and south into Taranaki and Hawke's Bay regions. Severe infestations can decimate white clover in pasture. In 1998, 2000 and 2002 , trials were established on a Warkworth Northland dairy farm to test a range of legume species for resistance or tolerance to CRW damage. Trial lines were regularly assessed for relative vigour and levels of CRW damage. No plant resistance was identified among white clover, red clover, lucerne, Lotus corniculatus, Lotus pedunculatus or Caucasian clover seed lines. A few lines were adapted to the site and showed tolerance to CRW. Red clover suffered the least damage and tolerant selections were made from a creeping red clover and nine white clover lines. Two further trials confirmed that red clover showed the least damage. Further cycles of selection are required to develop the potential tolerance shown in field tests. Red clover or a well-adapted white clover offers potential to cope with the CRW stress.
\end{abstract}

Keywords: clover root weevil, clover selections, legume tolerance, Sitona lepidus

\section{Introduction}

The clover root weevil (CRW) Sitona lepidus was first recorded on a dairy farm near Hamilton in March 1996. (Barratt et al. 1996). A delineation survey at that time indicated CRW was distributed in pasture through north Waikato, the coastal areas of the Bay of Plenty and in the south Auckland region. A further survey in 1997 indicated that CRW had extended its range over a year by an average of $35 \mathrm{~km}$ (Willoughby \& Addison 1997). Populations of CRW recorded in New Zealand were 10 times greater than found in overseas surveys. It is now present throughout the northern North Island, and has moved south into the Taranaki and Hawke's Bay region (B. Willoughby unpublished data).

The performance of white clover (Trifolium repens L.) is important as a source of high quality forage for animal production and for the nitrogen it contributes for associated grass growth (Cooper et al. 1997). Based on the worldwide distribution of CRW there will be no climatic limitations preventing the weevil spreading throughout New Zealand. Severe infestations in the North Island are continuing to remove white clover from the pasture particularly in recently infested areas. Adult CRW feed above ground on clover foliage, the smaller larvae feed on clover nodules, and the larger larvae tend to feed on clover roots and stolons. Overseas laboratory studies showed that, when given a choice of legume species, CRW adults consumed significantly less Lotus corniculatus and L. pedunculatus leaf material than white clover (Murray \& Clements 1994). In laboratory studies these authors found no difference in feeding levels between white clover cv Olwen and red clover (Trifolium pratense) cv Marcom, in $48 \mathrm{~h}$ choice and no-choice experiments. However, Murray (1996) reported less feeding on red clover than white clovers (cultivars not specified), and less egg laying by CRW on red clovers. New Zealand field studies have also shown that Lotus is not a preferred host plant for CRW and that shoot damage on red clover is intermediate between Lotus and white clover (Eerens et al. 2001). Recent research under controlled conditions at Ruakura has confirmed that CRW adults strongly prefer white clover to red clover (Gerard \& Crush 2003).

Currently in New Zealand there are research programmes underway looking at management options, legume tolerance and biological control measures for CRW. This paper reports on the field evaluation of a range of legume species for their tolerance to CRW.

\section{Materials and methods}

In 1998 CRW was causing widespread damage in the Warkworth area (M. Blackwell pers. comm.). A site for legume evaluation trials was located on the dairy farm property of Brett Pendergrast, Thompson Road, Warkworth. Trials were established in 1998, 2000 and 2002. The soil type is a Warkworth clay and sandy loam prone to winter pugging. The resident pasture was predominantly perennial ryegrass with low levels of resident buttercup (Ranunculus repens $L$ ) and white clover. A double spraying 3-4 months prior to planting with dicamba spray at 2 litres/ha was used to remove the white clover. 
In each trial, plants were established from seed lines germinated in petri dishes and then glasshouse grown in trays for approximately 2 months. Individual plant lines were established at the trial site by planting 10 plants per $1 \mathrm{~m}$ row with $1 \mathrm{~m}$ spacings between rows. Trial lines were put out in a randomised block design. Visual estimations on a $0-10$ scale were made of relative herbage yield $(0=$ poor growth and $10=$ excellent $)$ and CRW leaf damage $(0=$ no damage and $10=$ high damage) prior to grazing. The presence of clover weevil larvae was checked by examining soil from within Trial 1 in August 1999. Three replicates of white clover and six of the red clover lines were sampled. The trial was unfenced with the paddock grazed in a typical seasonal rotation by dairy cows.

\section{Trial 1}

To test the presence of tolerance or resistance to CRW, 118 white clover lines covering a wide range of origin, as well seven lines of red clover, five of $L$. corniculatus, six of $L$. pedunculatus, five of lucerne (Medicago sativa $L$ ) and seven of Caucasian clover (Trifolium ambiguum), were planted in early spring 1998. Information from this trial was collected by regular estimates / assessments of growth and CRW leaf damage from October 1998 until March 2000. The trial continued until May 2000 and then, with the increasing loss of surviving plants, the best nine white clover lines and one red clover line was identified. Stolon cuttings were removed for seed production and subsequent re-screening in Trial 2.

\section{Trial 2}

On the basis of earlier results in September 2000 plants from the seeds of nine white clover seed lines selected with possible tolerance to CRW and one creeping red clover selection were established at the same site as Trial 1. This trial of 50 lines included some of the original selected red and white clover lines from Trial 1 and a number of commercial controls. This experiment was scored for relative growth on six occasions from November 2000 until August 2001. CRW leaf damage scores were recorded on three occasions in November and December 2000 and January 2001.

\section{Trial 3}

This trial was planted in August 2002 with 12 red clover lines and 50 white clover breeding lines including some that, individually, had been selected for toler ance to nematodes, clover flea or CRW. This trial was scored four times and is on-going. Similar trials are being conducted in other districts, eg. Watson et al. (2002).

\section{Results and discussion}

\section{Trial 1}

Trial plants were initially free of adult CRW damage symptoms but the appearance of leaf damage in mid January confirmed that the pest was distributed throughout the trial paddock. From this date onwards a significant loss of vigour and persistence occurred in all clover lines and legume species. The mean growth scores (Table 1) for 12 observations to March

Table 1 Mean relative growth scores from October 1998 to March 2000 for legume species tested in Trial 1.

\begin{tabular}{lc}
\hline Selection & Mean ${ }^{1}$ \\
\hline White clover & 2.67 \\
Red clover & 4.17 \\
Caucasian clover & 0.95 \\
Lucerne & 0.99 \\
Lotus corniculatus & 1.77 \\
Lotus pedunculatus & 2.17 \\
LSD $(0.05)$ & 0.52 \\
\hline${ }^{1} 0=$ poor $10=$ excellent & \\
\hline
\end{tabular}

showed that none of the legume species were resistant to CRW. Most susceptible was Caucasian clover and lucerne, then L. corniculatus and L. pedunculatus. These species were not adapted to the clay soil and or early grazing after establishment. Damage levels varied considerably among the 118 white clover lines while the red clover lines showed the least amount of damage. A soil pest fauna sampling undertaken in August 1999 confirmed that CRW was the major insect pest present. High CRW densities (Table 2) under

Table 2 Clover root weevil larval densities under individual plants in Trial 1 (August 1999).

\begin{tabular}{lcc}
\hline Surviving clover species & Numbers $/ \mathrm{m}^{2}$ & Range \\
\hline White clover & 780 & $446-1562$ \\
Red clover & 724 & $223-1115$ \\
\hline
\end{tabular}

surviving red and white clover plants were likely to be providing intense selection pressure. Sampling of individual plants showed all had some CRW damage.

\section{Trial 2}

The trial planted in late August showed widespread CRW leaf damage from early November. Soil samples to record pest populations were not taken. The distinctive leaf damage indicated the pest was present throughout the trial. One of the unselected white clover lines (C19756) scored significantly higher than all others. In the final noting CRW leaf damage in January was similar among the white clover lines while the red clover selections were relatively undamaged (Table 3). 
Table 3 Relative Clover root weevil leaf damage scores in spring/summer 2000/2001 for Trial 2.

\begin{tabular}{lc}
\hline Selection & Mean ${ }^{1}$ \\
\hline White clover lines (45) & 6.13 \\
Red clover lines $(5)$ & 1.5 \\
LSD $(0.05)$ & 0.44 \\
\hline $10=$ poor $10=$ excellent & \\
\hline
\end{tabular}

Trial 3

The trial objective was to test pools of material developed for tolerance to CRW, nematodes, and clover flea. After 6 months, CRW has severely reduced vigour of most white clover lines. Mean growth scores for the 50 white clover lines declined between October and April (Table 4). In contrast the

Table 4 Mean relative plant growth scores from November 2002 to April 2003 for species tested in Trial 3 (4 assessments).

\begin{tabular}{lc}
\hline Selection & Mean $^{1}$ \\
\hline Selection white clover lines (7 CRW selection) & 5.15 \\
White clover lines (50) & 4.61 \\
Red clover lines (12) & 6.75 \\
Red clover (3 CRW selection) & 6.98 \\
LSD (0.05) total clover & 0.39 \\
LSD (0.05) clover selection & 0.55 \\
\hline${ }^{10}=$ poor 10 = excellent & \\
\hline
\end{tabular}

12 red clover lines had increased in vigour over this period. Seven of the original white clover CRW selections have retained some vigour and were included in the top ranking lines. Two other white clover selections, C19756 and C19751, were also performing well.

The initial trial in 1998 showed all legume species suffered some degree of damage from CRW but there was sufficient variation in vigour among the lines of red and white clovers to enable selection of plants with improved tolerance to CRW. In all three field evaluations, red clover has shown the least damage as a species. Laboratory feeding trials have also demonstrated that adult weevils have a strong preference for white over red clovers but have indicated some feeding habituation to red clover by CRW adults when confined to these plots (Gerard \& Crush 2003). CRW adults previously fed solely on red clover showed a less marked preference for white clover when offered the choice of red and white clovers than $\mathrm{CRW}$ previously fed on white clover. Watson et al. (2002) suggested that larval populations were influenced by favour ability of leaves to attract adults and the plant vigour affecting the retention of egg laying adults.

\section{Conclusions}

Prior to the CRW invasion of the Warkworth trial site the dairy farmer experienced a regular bloat problem due to the white clover content of the pasture. CRW initially decimated that natural clover population but over the last $2-3$ years recovery of clover has been observed in the paddocks adjacent to the trials. This may have been because of hot dry conditions that reduce the impact of CRW (Eerens et al. 1998) and other factors, yet to be determined, may be combining to ameliorate the CRW effect on white clover.

The selections made within the white and red clover lines in this study indicated a positive trend towards resistance but will require further cycles of selection and field-testing to confirm progress. Our trial results suggest that white clover has some variation in tolerance to CRW but, in the short term, red clover offers more potential as a pasture legume in the presence of this pest. However red clover is regarded as a short lived pasture species and would require special management to utilise its tolerance to CRW. Farmers renovating pastures in CRW areas should consider sowing either a red clover or a white clover that is very well adapted to their environment and management. It is likely that white clovers with good agronomic adaptation and that are wellmanaged cope better with the additional stress of CRW than clovers that are already struggling. Further work is required to sort out the implications for red clover pastures of habituation of CRW to red clover, and to confirm a reported decrease in fecundity of CRW feeding on red clover (Murray 1996).

\section{ACKNOWLEDGEMENTS}

This research was co-funded by Meat \& Wool NZ, Dairy Insight, Deer Industry NZ, and FRST. The authors thank David Baird for statistical advice and Vaughan Cooper, Jeff Couchman, Mike George, Mariana Knox and Shirley Nichols, for technical support. We would also like to thank Brett Pendergrast for the continued use of the trial site at Warkworth.

\section{REFERENCES}

Barratt, B.I.P.; Barker, G.M.; Addison, P.J. 1996. Sitona lepidus Gyllenhal (Coleoptera: Curculionidae), a potential clover pest new to New Zealand. New Zealand Entomologist 19: 23 - 30.

Cooper, B.M.; Clifford, P.T.P.; Williams, W.M. 1997. Development of white clover (Trifolium repens L) cultivar Grasslands Challenge 9G23). Proceedings of the New Zealand Grassland Association 59: 99 - 102.

Eerens, J.P.J.; Willoughby, B.; Kettlewell, F.; 
Hardwick, S.; Bay, S. 1998. The clover root weevil in northern pastures: on-farm observations of its impact on white clover. Proceedings of the New Zealand Grassland Association 60: 287-290.

Eerens, J. P. J.; Cooper, B. M.; Willoughby, B. E.; Woodfield, D. R. 2001. Searching for clover root weevil (Sitons lepidus) resistance/tolerance - A progress report. Proceedings of the New Zealand Grassland Association 63: 177-181.

Gerard, P. J.; Crush, J. R. 2003. Feeding habituation to red clover by clover root weevil adults. New Zealand Plant Protection 56: (in press).

Murray, P.J.; Clements, R.O. 1994. Investig ations of the host feeding preferences of Sitona weevils found commonly on white clover (Trifolium repens $L$ ) in the UK. Entomologia Experimentalis et Applicata 71: 73-79.

Murray, P. J. 1996. Influence of food source on feeding, longevity and fecundity of Sitona flavescens (Coleoptera: Curculionidae), a major pest of white clover in the UK. pp. 118-121. In: Recent research and development on white clover in Europe. Ed. Frame, J. REU Technical Series, FAO, Rome.

Willoughby, B.; Addison, P. 1997. Assessment of the dispersal of Sitona lepidus (clover root weevil) in the North Island of New Zealand. Proceedings of the Plant Protection Conference 50: 33-36.

Watson, R.N.; Eerens, J.P.J.; Davis, L.T. 2002. Clover root weevil feeding and larval numbers on white and red clover seedlines. New Zealand Plant Protection 55: 252-257. 